Volume: 13 Issue: 3 Year: 2016

\title{
The economic impacts of international student mobility in the globalization process ${ }^{1}$
}

\author{
Faruk Levent ${ }^{2}$
}

\begin{abstract}
Globalization, which has various effects on economic, financial, political, sociological and cultural developments, also influences the field of education. One of the outcomes that arise due to the effects of globalization is related to the increase in international student mobility. This has paved the way for the emergence of a new market area in which international students are regarded as a source of income. Purpose of this study is to examine the economic impacts of international student mobility in the globalization process. The document analysis is used in the study. In this study, the data analysis consists of three parts. The first part is about the cost of international education while the second part explicates the economic impacts of international student mobility. Finally, the third part reviews policies aimed at increasing the number of international students. According to the information obtained from this study international students provide significant revenue to the economy of their host country by bearing the cost of tuition fees and noneducational expenses as well as by contributing to the production of knowledge and technology.
\end{abstract}

Keywords: International student mobility; International education; Globalization; Economic impact.

\section{Introduction}

Internationalization has become an essential element of higher education in the world. In the upcoming years it is expected for the higher education to globalize in terms of institutional aspects, and consequently it is expected for the internationalism to become a strong trend in an increasing intensity (Altbach, 2006, p. 123). One of the most important indicators of internationalization in higher education is student mobility. Student mobility is concerned with the students who go abroad for educational purposes (Teichler, 1999; Kelo, Teichler and Wächter, 2006) and it is considered as an important dimension of globalization by Organization for Economic Cooperation and Development (OECD, 2014).

Higher education institutions are precipitating factors for both the local and national economies (Bessette, 2003; Altbach, Reisberg and Rumbley, 2009; Altbach and Reisberg 2013; Bergerhoff, Borghans, Seegers and van Veen, 2013; de Wit and Hunter 2014; Peterson 2014). Individuals who go through higher education process contribute to local and national economies firstly by qualified higher education expenses they bear throughout their education and secondly by becoming a part of the qualified workforce in the host country (Bleaney, Binks, Greenaway, Reed and Whynes, 1992). In addition, this demand for greater reliance on the knowledge-based economy has increased considerably. Knowledge-producing universities are organizations that

\footnotetext{
${ }^{1}$ This study was presented verbally at the 1st International Higher Education Studies Conference (IHEC) 2015

2 Assist. Prof. Dr., Marmara University, Ataturk Faculty of Education, Department of Educational Sciences, faruk.levent@marmara.edu.tr
} 
play an important role in the economic development of a country (Oplatka and Hemsley-Brown, 2010; Universities UK, 2015).

Many students from developing economies migrate to developed countries, to study in the schools and universities of developed countries. International student mobility is an important medium that allows high-skilled immigrants to come to the developed countries (Suter and Jandl, 2006; Borjas, 2009; Mok, 2010). Economic theory suggests that high-skilled immigration generally has positive effects on the economy of the host country (Cao, 1996; Docquier and Marfouk, 2006; Chiswick, 2011; Bergerhoff, Borghans, Seegers and van Veen, 2013).

International student mobility affects many aspects of the higher education policies, including tuition fees, the medium of instruction and the quality of the higher education institutions (DeVoretz, 2006, p. 30). In addition, direct and indirect economic advantages provided by international education attracted the interest of countries to receive more international students. Higher education policies of these countries which emerge as a result of this phenomenon have contributed to international student mobility (Mok, 2003; Naidoo, 2007; Cloete, Bailey, Bunting and Maassen, 2011).

According to the statistical data provided by the OECD education directorate, more than 4,5 million students at the higher education level have studied outside their own country in 2012 (OECD, 2014). It is estimated for that number to increase to 5,8 million in 2020 (Böhm, Follari, Hewett, Jones, Kemp, Meares, Pearc and Van Cauter, 2004), and 8 million in 2025 (Altbach and Bassett, 2004). International student mobility effects all aspects of global society including economy, science, technology, industry, business, politics and culture (Moor and Henderkx, 2013). Purpose of this study is to examine the economic impacts of international student mobility in the globalization process.

\section{Methods}

The study utilizes the document analysis. Document analysis involves the analysis of written and printed documents regarding the topics being studied (Cohen, Manion and Morrison, 2000). Books, thesis, articles and electronic sources related to international education were reviewed within this study. In addition, to demonstrate the economic dimension of international student mobility, studies of national and international organizations such as OECD (Organization for Economic Cooperation and Development), UNESCO (United Nations Educational, Scientific and Cultural Organization), WES (World Education Services) and NAFSA (Association of International Educators) were also reviewed to analyze the global trends and possible advances in the world. Accordance with the information obtained from literature this study was composed of three parts. In the first part, the cost of international education; in the second part, the economic revenue derived from international student mobility; in the third part, policies of developed countries to increase the income from international education were discussed.

\section{Findings}

\subsection{The cost of international education}

Educational costs are one of the most important factors shaping the international educational mobility (Ivy, 2001; Naidoo, 2007; Varghese, 2008). Studying abroad is expensive. Educational costs vary depending on the nationality of student, the program, success level and the preferred study destination. 
Levent, F. (2016). The economic impacts of international student mobility in the globalization process. Journal of Human Sciences, 13(3), 3853-3870. doi:10.14687/ihs.v13i3.3877

Tuition policies of OECD member countries and G20 countries for international students are given in Table 1.

Table 1. OECD and Other G-20 Countries' Tuition Policies

\begin{tabular}{|l|l|}
\hline Tuition fee structure & OECD and other G20 countries \\
\hline $\begin{array}{l}\text { Higher tuition fees for international } \\
\text { students than for domestic students }\end{array}$ & $\begin{array}{l}\text { Australia (1), Austria (2), Belgium (2) (3), Canada, the } \\
\text { Czech Republic (2) (4), Denmark (2) (4), Estonia (2), } \\
\text { Ireland (4), the Netherlands (2), New Zealand (5), Poland } \\
\text { (2), the Russian Federation, Sweden (6), Turkey, the } \\
\text { United Kingdom (2), the United States (7) }\end{array}$ \\
\hline $\begin{array}{l}\text { Same tuition fees for international and } \\
\text { domestic students }\end{array}$ & $\begin{array}{l}\text { France, Germany, Italy, Japan, Korea, Mexico (8), Spain, } \\
\text { Switzerland (9) }\end{array}$ \\
\hline $\begin{array}{l}\text { No tuition fees for either international or } \\
\text { domestic students }\end{array}$ & Finland, Iceland, Norway \\
\hline
\end{tabular}

(1) International students (except students from New Zealand) are not eligible for government-subsidised places in Australia and therefore pay the full fee. While this typically results in international students having higher tuition fees than domestic students, who are usually given subsidised places, some domestic students in public universities and all students in independent-private universities pay the full fee and pay the same tuition fees as international students.

(2) For non-European Union or non-European Economic Area students.

(3) In Belgium (Flemish Community), different tuition is allowed only if at least $2 \%$ of students in the institutions are from outside the EEA area.

(4) No tuition fees for full-time domestic students in public institutions.

(5) Except for students in advanced research programmes, or for students from Australia.

(6) For students from outside the EU/EEA area and Switzerland.

(7) In public institutions, international students pay the same fees as domestic out-of-state students. However, since most domestic students are enrolled in-state, international students pay higher tuition fees than most domestic students, in practice. In private universities, the fees are the same for national and international students.

(8) Some institutions charge higher tuition fees for international students.

(9) There is a negligible difference between the average annual tuition fees charged to domestic and mobile students.

Source: "Education at a glance 2014: OECD indicators", adapted from OECD (2014)

As seen in Table 1, most countries charge higher tuition fees for international students. The United States of America, the United Kingdom and Russia are among the countries that host higher number international students. This situation shows that tuition fee is not a stand-alone factor that impacts student preferences (Mazzarol and Soutar, 2002; Pimpa, 2003; Maringe, 2006; Maringe and Carter, 2007; Phang, 2013). Nevertheless international students consider tuition fees while comparing equivalent qualifications in terms of quality and training facilities (Naidoo, 2007; Soo and Elliott, 2010).

According to "Education at a Glance 2014" report which was published by OECD, the number of international students in the countries, where no tuition fee taken, has increased rapidly and this situation aggravated the higher education costs for the state. Upon this, some countries started to modify their policies regarding international students tuition fees. For example, Denmark and Sweden had no policy that charges any tuition fee for international students until 2006-2007, then they modified their pricing policy. Nowadays international students pay more tuition fees compared to domestic students in these two countries (OECD, 2014). However, Finland, Iceland and Norway still are not charging any tuition fees to international students.

A research that was conducted by Ipsos MORI on behalf of HSBC's Retail Banking and Wealth Management (RBWM) revaled the total annual cost of studying in different countries by 
Levent, F. (2016). The economic impacts of international student mobility in the globalization process. Journal of Human Sciences, 13(3), 3853-3870. doi:10.14687/ihs.v13i3.3877

collecting information from 15 different countries and more than 4500 families (HSBC, 2014). Annual tuition fees, cost of living and total cost for international education are given in Table 2 .

Table 2. Cost of International University Study

\begin{tabular}{|l|c|c|c|}
\hline Country & $\begin{array}{c}\text { Annual university } \\
\text { fees (USD) }\end{array}$ & $\begin{array}{c}\text { Annual cost of living } \\
\text { (USD) }\end{array}$ & $\begin{array}{c}\text { Annual cost total } \\
\text { (USD) }\end{array}$ \\
\hline Australia & 24.081 & 18.012 & 42.093 \\
\hline Singapore & 18.937 & 20.292 & 39.229 \\
\hline United States & 24.914 & 11.615 & 36.564 \\
\hline United Kingdom & 21.365 & 13.680 & 35.045 \\
\hline Hong Kong & 13.444 & 18.696 & 32.140 \\
\hline Canada & 16.746 & 13.201 & 29.947 \\
\hline France & 247 & 16.530 & 16.777 \\
\hline Indonesia & 4.378 & 8.527 & 12.905 \\
\hline Brazil & 59 & 12.569 & 12.627 \\
\hline Malaysia & 2.453 & 10.488 & 12.941 \\
\hline Taiwan & 3.338 & 8.573 & 11.911 \\
\hline Turkey & 1.276 & 10.089 & 10.729 \\
\hline China & 3.844 & 6.886 & 9.460 \\
\hline Mexico & 750 & 8.710 & 5.642 \\
\hline India & 581 & 5.062 & \\
\hline
\end{tabular}

Source: "International education”, adapted from HSBC (2014)

As seen in Table 2, Australia is the most expensive country in terms of annual cost of education. Singapore, United States of America and United Kingdom follow Australia respectively in terms of annual cost of education. India and Mexico are the two countries with the least annual educational cost.

Tuition fees and living costs abroad can be covered by international students themselves, their families, their employers, universities they are affiliated with or their respective governments. Information about the resources for international students' educational costs in United States of America in 2014-2015 academic years are given in Table 3.

Table 3. International Students' Primary Source of Funding By Academic Level, 2014/15

\begin{tabular}{|c|c|c|c|c|c|c|}
\hline \multirow[b]{2}{*}{$\begin{array}{l}\text { Primary source of } \\
\text { funding }\end{array}$} & \multicolumn{2}{|c|}{ Total } & \multicolumn{4}{|c|}{$\begin{array}{r}\text { Academic Level (\%) } \\
\end{array}$} \\
\hline & $2014 / 15$ & $\%$ of Total & Undergraduate & Graduate & $\begin{array}{l}\text { Non- } \\
\text { Degree }\end{array}$ & OPT \\
\hline Personal and Family & 619.999 & 63,6 & 79,9 & 55,3 & 54,4 & 43,6 \\
\hline $\begin{array}{l}\text { U.S. College or } \\
\text { University }\end{array}$ & 203.337 & 20,9 & 7,9 & 36,3 & 28,0 & 8,8 \\
\hline $\begin{array}{l}\text { Foreign Government } \\
\text { or University }\end{array}$ & 75.042 & 7,7 & 9,2 & 5,0 & 13,9 & 0,7 \\
\hline Current Employment & 48.632 & 5,0 & 0,1 & 0,6 & 0,2 & 44,4 \\
\hline $\begin{array}{l}\text { Foreign Private } \\
\text { Sponsor }\end{array}$ & 9.735 & 1,0 & 1,0 & 1,1 & 0,8 & 0,9 \\
\hline U.S. Government & 4.915 & 0,5 & 0,2 & 0,7 & 1,1 & 0,0 \\
\hline U.S. Private Sponsor & 4.124 & 0,4 & 0,6 & 0,3 & 0,6 & 0,1 \\
\hline $\begin{array}{l}\text { International } \\
\text { Organization }\end{array}$ & 2.489 & 0,3 & 0,2 & 0,2 & 0,7 & 0,0 \\
\hline Other Source & 6.653 & 0,7 & 0,9 & 0,4 & 0,3 & 1,5 \\
\hline Total & 974.926 & 100,0 & 398.824 & 362.228 & 93.587 & 120.287 \\
\hline
\end{tabular}

Source: "Open Doors Report on International Educational Exchange", adapted from Institute of International Education (2015) 
As seen in Table 3, a significant portion $(\% 63,6)$ of educational costs of international students coming to study in America are met by personal funds and by family funds. However, these students' financial support rate $(\% 13,7)$ provided by foreign government and university or current employment and foreign private sponsor is quite high.

\subsection{Economic revenue derived from international student mobility}

International education market has become an industry that provides significant resources in terms of both economic return and information management and technology production (Funk, 2001). International student numbers and market share percentages in top ten countries that took the lead in international education is given in Table 4.

Table 4. International Student Numbers and Market Share Percentages in Top Ten Countries (2012)

\begin{tabular}{|l|c|c|}
\hline Countries & $\begin{array}{c}\text { Number of } \\
\text { International } \\
\text { Students }\end{array}$ & $\begin{array}{c}\text { Approximate } \\
\text { Market Share } \\
\text { Ratio (\%) }\end{array}$ \\
\hline United States & 784.427 & 18 \\
\hline United Kingdom & 416.693 & 11 \\
\hline Australia & 249.868 & 7 \\
\hline France & 239.344 & 7 \\
\hline Germany & 196.619 & 5 \\
\hline Russian Federation & 138.496 & 4 \\
\hline Japan & 135.803 & 4 \\
\hline Canada & 135.187 & 3 \\
\hline China* & 132.467 & 2 \\
\hline Italy & 82.450 & 2 \\
\hline
\end{tabular}

* Include Hong Kong and Macao

Source: "Global flow of tertiary-level students" adapted from UNESCO Institute for Statistics (2016)

As seen in Table 4, United States of America has the largest share in this market with 784.427 international students. This is approximately $18 \%$ of the total international student mobility. United Kingdom has the second largest share with 416.693 students, and this is approximately $11 \%$ of the total international student mobility.

Economic income from international education in some developed countries is described below with quantitative data.

\subsubsection{United States of America}

United States of America (USA), the most preferred country by international students, has been hosting international higher education students from many different countries (UNESCO, 2012). USA became the center of attraction for international students after World War II. American universities has become the best research universities in the world especially in 1970s and 1980s, and they have moved to the forefront of international education (Wildavsky, 2010).

Education is the fifth largest export source in America, this shows the contribution of international students to the country economy (Douglass and Edelstein, 2009). 819.644 international students studied in USA in 2013-2014 academic year (NAFSA, 2015). The contribution of these students to American economy is given in Table 5. 
Levent, F. (2016). The economic impacts of international student mobility in the globalization process. Journal of Human Sciences, 13(3), 3853-3870. doi:10.14687/jhs.v13i3.3877

Table 5. Net Contribution to U.S. Economy by Foreign Students (2013-14)

\begin{tabular}{|l|c|}
\hline Contribution from tuition and fees to U.S. economy: & $\$ 19.754 .000 .000$ \\
\hline Contribution from living expenses: & $\$ 16.265 .000 .000$ \\
\hline Total contribution by foreign students: & $\$ 36.019 .000 .000$ \\
\hline Less U.S. support of \%26,8: & $-\$ 9.669 .000 .000$ \\
\hline Plus dependents' living expenses: & $+\$ 442.000 .000$ \\
\hline $\begin{array}{l}\text { Net contribution to U.S. Economy by foreign students and } \\
\text { their families: }\end{array}$ & $\$ \mathbf{2 6 . 7 9 2 . 0 0 0 . 0 0 0}$ \\
\hline
\end{tabular}

Source: "Economic analysis for academic year 2013-2014", adapted from NAFSA (2015)

As seen in Table 5, international students who had scholarship from their respective country or use their own resources, contributed about 26,8 billion dollars to American economy in 20132014 academic year (NAFSA, 2014). All this revenue earned from international students are being spent on activities and projects in this field in accordance with government policy. These investments increase further economic income (Douglass ve Edelstein, 2009). The number of international students has been increased to 974926 in 2014-2015 academic year. Contribution of these students to American economy is about 30,5 billion dollars in 2014-2015 academic year. Besides the economic benefits, another attention-grabbing note is those successful and talented students prefer to work for major American companies instead of returning to their country after graduating in USA (NAFSA, 2015). Therefore, international students both provide contribution to American economy during their education and they also provide contribution to the development of scientific, technological and military fields in USA.

Table 6. Net Jobs Created/Supported by Foreign Students and Their Families (20132014)

\begin{tabular}{|l|c|}
\hline Jobs directly created/supported: & 123.465 \\
\hline Jobs indirectly created/supported: & 340.007 \\
\hline $\begin{array}{l}\text { Net jobs created/supported in the State economy by foreign } \\
\text { students and their families: }\end{array}$ & $\mathbf{2 1 6 . 5 4 2}$ \\
\hline
\end{tabular}

Source: "Economic analysis for academic year 2013-2014", adapted from NAFSA (2015)

As seen in Table 6, the total contribution of international students' own and families to the employment in the United States of America is 340.007 dollar in 2013-2014 academic year. Besides the contribution made by international students to employment in America, family members of international students directly contribute to the economy of country.

Table 7. Contribution to U.S. Economy by Foreign Students' Dependents (2013-14)

\begin{tabular}{|l|l|l|l|}
\hline Spouses' contribution & Children's contribution \\
\hline Percent of married students: & $\% 7,3$ & Number of couples in the U.S.: & 64.336 \\
\hline Percent of spouses in the U.S.: & $\% 85,0$ & Number of children per couple: & 0,6 \\
\hline Number of spouses in the U.S.: & 64.336 & Number of children in the U.S.: & 38.486 \\
\hline $\begin{array}{l}\text { Additional expenses for a spouse: } \\
\text { (\% of student living expenses) }\end{array}$ & $\% 25,0$ & $\begin{array}{l}\text { Additional expenses for a child: } \\
\text { (\% of student living expenses) }\end{array}$ & $\% 20,0$ \\
\hline Spouses' contribution: & $\$ 299.000 .000$ & Children's contribution: & $\$ 143.000 .000$ \\
\hline Net contribution to U.S. economy by foreign students' dependents: & $\$ 442.000 .000$ \\
\hline
\end{tabular}

Source: 'Economic analysis for academic year 2013-2014", adapted from NAFSA (2015) 
Levent, F. (2016). The economic impacts of international student mobility in the globalization process. Journal of Human Sciences, 13(3), 3853-3870. doi:10.14687/jhs.v13i3.3877

The contribution to American economy by international students' dependents is given in Table 7 . As seen in the table, the total contribution of international students' spouses and children to American economy in 2013-2014 academic year is 442 million dollars.

All states other than Puerto Rico and Virgin Islands earn substantial revenues from international students in America. Financial contribution rates made by some states which took the lead in international education to American economy are given in Table 8.

Table 8. Financial Contribution by Some State (2013-14)

\begin{tabular}{|l|c|c|c|c|c|c|}
\hline State & $\begin{array}{c}\text { \# of Foreign } \\
\text { Students }\end{array}$ & $\begin{array}{c}\text { Tuition } \\
\text { and Fees } \\
\text { (millions) }\end{array}$ & $\begin{array}{c}\text { Living Expenses } \\
\text { and Dependents } \\
\text { (millions) }\end{array}$ & $\begin{array}{c}\text { Less U.S. } \\
\text { Support } \\
\text { (millions) }\end{array}$ & $\begin{array}{c}\text { Total } \\
\text { Contribution } \\
\text { (millions) }\end{array}$ & $\begin{array}{c}\text { \# of Jobs } \\
\text { Created/ } \\
\text { Supported }\end{array}$ \\
\hline California & 121.647 & $\$ 2.547 .3$ & $\$ 2.680 .0$ & $\$ 1.151 .3$ & $\$ 4.076 .0$ & 47.702 \\
\hline New York & 98.906 & $\$ 2.481 .8$ & $\$ 2.138 .6$ & $\$ 1.325 .3$ & $\$ 3.295 .1$ & 40.331 \\
\hline Massachusetts & 51.240 & $\$ 1.594 .5$ & $\$ 1.113 .7$ & $\$ 789.2$ & $\$ 1.918 .9$ & 26.553 \\
\hline Texas & 64.277 & $\$ 968.2$ & $\$ 1.068 .6$ & $\$ 577.3$ & $\$ 1.459 .5$ & 18.671 \\
\hline Pennsylvania & 41.446 & $\$ 1.148 .3$ & $\$ 801.2$ & $\$ 558.3$ & $\$ 1.391 .2$ & 20.862 \\
\hline Illinois & 42.527 & $\$ 1.039 .0$ & $\$ 813.4$ & $\$ 591.3$ & $\$ 1.261 .1$ & 19.036 \\
\hline Florida & 36.249 & $\$ 754.4$ & $\$ 695.4$ & $\$ 375.6$ & $\$ 1.074 .2$ & 13.903 \\
\hline Michigan & 29.648 & $\$ 782.5$ & $\$ 479.7$ & $\$ 335.3$ & $\$ 926.9$ & 12.763 \\
\hline Ohio & 32.498 & $\$ 680.6$ & $\$ 560.6$ & $\$ 329.6$ & $\$ 911.6$ & 12.400 \\
\hline Indiana & 26.406 & $\$ 671.6$ & $\$ 458.3$ & $\$ 290.3$ & $\$ 839.6$ & 11.431 \\
\hline Washington & 25.554 & $\$ 443.9$ & $\$ 435.8$ & $\$ 142.7$ & $\$ 737.0$ & 7.539 \\
\hline
\end{tabular}

Source: "Economic analysis for academic year 2013-2014", adapted from NAFSA (2015)

As seen in Table 8, California, New York, Massachusetts and Texas are the states where international students are the most intense in America. Income of these states from international education is more than many other countries' GDP (Gross Domestic Product). The Federal Government in America encourages all states to attract more international students.

\subsubsection{United Kingdom}

United Kingdom (UK) is the most preferred European country by international students for higher education (UNESCO, 2012). International students who come to UK to study make a huge contribution to the UK economy. Each international student in higher education on average pays fees of about $£, 10,000$ a year and spends more than this again while they are here (Her Majesty's Government, 2013). According to Universities UK (2011) data, the contribution of international students to UK economy was $f, 8,245$ in 2010 . At the same resource it is stated that the contribution of international students to UK economy is estimated to be $\mathcal{f}_{13}$.222 in 2020 and it will be $f_{1} 16.895$ in 2025 .

A research report conducted by Universities UK (2014) reveals that the students from non EU countries contributes to the budget of the institution which they have education (through tuition fees and accommodation payments) as well as the local economy (through off-campus spending) contributions. In 2011-2012 academic year, United Kingdom acquired f,10,7 bn export revenues in the higher education sector. Approximately $30 \%$ of this revenue was composed of fees paid by international students. However, the contribution of international students to the country's economic sitiuation is not limited to fees paid to the educational institution. Off-campus spending of international students is also an important source of income. International students throughout the United Kingdom spent $f^{3}, 4$ bn for off-campus such as rent, food, the entertainment and consumer goods during the 2011-2012 academic year. Throughout United Kingdom, spending of approximate 300,000 international students enrolled in universities 
Levent, F. (2016). The economic impacts of international student mobility in the globalization process. Journal of Human Sciences, 13(3), 3853-3870. doi:10.14687/jhs.v13i3.3877

provides employment for the country. It is stated that international students provide about 137.000 (this figure represents 18\% of overall employment) off-campus and on-campus full-time employment. For example, international students in the northwest of England spent f,387 million in off-campus in 2011-2012 academic year. This situation led to the creation of additional employment in the region by contributing to the local economy.

The higher education export revenue of United Kingdom gained in 2011-2012 academic year and the contribution of non-EU students to the economy are given in Table 9.

Table 9. UK Higher Education Export Earnings and The Economic Impact of Non-EU Students in 2011-12

\begin{tabular}{|l|l|}
\hline Area of expenditure & Impact \\
\hline Tuition fees & $\AA^{3.24}$ bn \\
\hline Accommodation costs & $\AA^{0.52}$ bn \\
\hline Off-campus spend & $\AA^{3.42}$ bn \\
\hline Visitors' spend & $\AA^{0.10}$ bn \\
\hline Research income (non-EU sources) & $\AA^{0.64 \text { bn }}$ \\
\hline Consultancy & $£^{0.26 \text { bn }}$ \\
\hline Total & $£ 8.18$ bn \\
\hline
\end{tabular}

Source: "The funding environment for universities 2014: International students in higher education: the UK and its competition" adapted from Universities UK (2014)

As seen in Table 9, the total expenditure of international students on fees, accommodation and off-campus amounted to just over $£ 7$ bn in 2011-12 academic year. Total export earnings from non-EU sources (which includes students but also other things such as income from research grants) were worth over $\AA_{8} 8$ bn in 2011-2012 academic year (Universities UK, 2014).

Table 10. Economic Impact of EU and Non-EU Students' Off-Campus Expenditure, By English Region, 2011-12

\begin{tabular}{|c|c|c|c|c|c|}
\hline \multirow[b]{2}{*}{ Region } & \multirow[b]{2}{*}{$\begin{array}{c}\text { International } \\
\text { students' off campus } \\
\text { expenditure }\end{array}$} & \multicolumn{2}{|c|}{$\begin{array}{c}\text { Impact within the } \\
\text { region }\end{array}$} & \multicolumn{2}{|c|}{$\begin{array}{c}\text { Total impact across } \\
\text { the UK }\end{array}$} \\
\hline & & $\begin{array}{l}\text { Output } \\
\text { generated }\end{array}$ & $\begin{array}{c}\text { Jobs } \\
\text { generated }\end{array}$ & $\begin{array}{l}\text { Output } \\
\text { generated }\end{array}$ & $\begin{array}{c}\text { Jobs } \\
\text { generated }\end{array}$ \\
\hline East of England & $£ 369 \mathrm{~m}$ & $£ 517 \mathrm{~m}$ & 4.365 & $£ 554 \mathrm{~m}$ & 4.691 \\
\hline East Midlands & $\AA^{293 \mathrm{~m}}$ & f358 m & 2.975 & $f^{4} 40 \mathrm{~m}$ & 3.719 \\
\hline London & $£ 1.200 \mathrm{~m}$ & $£ 1.300 \mathrm{~m}$ & 11.337 & $£ 1.700 \mathrm{~m}$ & 14.763 \\
\hline North East & $£ 213 \mathrm{~m}$ & $£ 237 \mathrm{~m}$ & 1.935 & $f^{3} 319 \mathrm{~m}$ & 2.703 \\
\hline North West & f387 m & $f, 473 \mathrm{~m}$ & 4.052 & f,581 m & 4.912 \\
\hline South East & $f^{2} 549 \mathrm{~m}$ & $f^{2} 718 \mathrm{~m}$ & 6.243 & $825 \mathrm{~m}$ & 6.977 \\
\hline South West & $£ 270 \mathrm{~m}$ & $£ 339 \mathrm{~m}$ & 2.492 & f,405 m & 3.428 \\
\hline West Midlands & $4.408 \mathrm{~m}$ & $4463 \mathrm{~m}$ & 3.921 & $6612 \mathrm{~m}$ & 5.180 \\
\hline Yorks. \& Humber & f380 m & $f^{2} 404 \mathrm{~m}$ & 3.515 & $£ 570 \mathrm{~m}$ & 4.824 \\
\hline
\end{tabular}

Source: "The funding environment for universities 2014: International students in higher education: the UK and its competition" adapted from Universities UK (2014)

As seen in Table 10, the economic impact of international students off-campus spending at all regions within the country is quite remarkable. For example, the campus spending of 
Levent, F. (2016). The economic impacts of international student mobility in the globalization process. Journal of Human Sciences, 13(3), 3853-3870. doi:10.14687/ihs.v13i3.3877

international students living in South West England and studying at university create $f_{4} 405$ million income in the 2011-2012 academic year.

\subsubsection{Australia}

Australia has considered international education as a door which opens to abroad and aimed at both economic and cultural development in this way. The strategy of this country is to become an international brand in education like England both to have economic wealth and qulified human power (Guruz, 2011). The number of international students who get education in Australia is given in Table 11.

Table 11. International Student Enrolment Data in Australia

\begin{tabular}{|l|c|c|c|}
\hline & $\mathbf{2 0 1 3}$ & $\mathbf{2 0 1 4}$ & Growth on \\
\hline Higher Education & 230.436 & 249.990 & $\% 8,5$ \\
\hline VET & 134.060 & 149.785 & $\% 11,7$ \\
\hline ELICOS & 115.023 & 137.469 & $\% 19,5$ \\
\hline Schools & 17.756 & 18.451 & $\% 3,9$ \\
\hline Non-award* & 27.902 & 34.165 & $\% 22,4$ \\
\hline Total in Australia & $\mathbf{5 2 5 . 1 7 7}$ & $\mathbf{5 8 9 . 8 6 0}$ & $\mathbf{0 1 2 , 3}$ \\
\hline
\end{tabular}

* Other' includes Foundation, Bridging and Enabling courses plus other courses that do not lead to a qualification under the Australian Qualifications Framework (AQF).

Source: "End of year summary of international student enrolment data" adapted from Australian Government, Department of Education and Training (2014)

As seen in Table 11, the number of international students who study in Australia increased by $\% 12,3$ in 2014 compared with 2013. Although most of these students were in higher education, there were a lot of students in VET (Vocational Education and Training) and ELICOS (English Language Intensive Courses for Overseas Students) institutions.

International education activities are at the first place in service industry for Australian exportation. When all industries are taken into account, it is at the second place after coal and iron exportation in terms of revenues. In 2009 Australian Higher Education has achieved 9,5 billion Australian Dollars of revenue from education services. In 2010, Australia has achieved a total of 19,1 billion Australian Dollars of revenue from education services (Australian Education International, 2011). And during 2013-2014 education year Australia had nearly 10,8 billion Australian Dollars of revenue from higher education services (Department of the Prime Minister and Cabinet, 2014).

\subsubsection{Canada}

Canada is the eighth country in the World in terms of international students number. In 2000 there were 36.450 international students in Canada and in 2011 the number of international students increased by $232 \%$ and became 120.960 (UNESCO, 2012).

In 2010, the expenses of education, accommodation and other spendings of international students were more than 8 billion Canadian Dollars. The effects of international education services to Canadian economy are given in Table 12. 
Levent, F. (2016). The economic impacts of international student mobility in the globalization process. Journal of Human Sciences, 13(3), 3853-3870. doi:10.14687/jhs.v13i3.3877

Table 12. Economic Impact of International Education Services in Canada (2010)

\begin{tabular}{|l|r|r|r|r|}
\hline & Total Expenditure & GDP & Employment & $\begin{array}{l}\text { Government } \\
\text { Revenue }\end{array}$ \\
\hline Newfoundland and Labrador & $\$ 40.670 .000$ & $\$ 27.614 .000$ & 370 & $\$ 1.480 .000$ \\
\hline Prince Edward Island & $\$ 27.760 .000$ & $\$ 6.191 .000$ & 60 & $\$ 621,400$ \\
\hline Nova Scotia & $\$ 217.167 .000$ & $\$ 123.568 .000$ & 1.890 & $\$ 12.000 .000$ \\
\hline New Brunswick & $\$ 93.576 .000$ & $\$ 66.975 .000$ & 1.030 & $\$ 3.425 .300$ \\
\hline Quebec & $\$ 1.014 .526 .000$ & $\$ 593.069 .000$ & 8.000 & $\$ 81.226 .000$ \\
\hline Ontario & $\$ 2.902 .608 .000$ & $\$ 1.808 .730 .000$ & 29.970 & $\$ 202.975 .000$ \\
\hline Manitoba & $\$ 153.784 .000$ & $\$ 87.342 .000$ & 1.640 & $\$ 10.831 .000$ \\
\hline Saskatchewan & $\$ 120.503 .000$ & $\$ 69.887 .000$ & 1.050 & $\$ 4.479 .000$ \\
\hline Alberta & $\$ 486.637 .000$ & $\$ 300.332 .000$ & 4.770 & $\$ 13.249 .000$ \\
\hline British Columbia & $\$ 1.864 .093 .000$ & $\$ 1.151 .116 .000$ & 21.460 & $\$ 66.897 .000$ \\
\hline $\begin{array}{l}\text { Yukon, Northwest Territories and } \\
\text { Nunavut }\end{array}$ & $\$ 623.000$ & $\$ 174.000$ & 0 & $\$ 8.000$ \\
\hline $\begin{array}{l}\text { Short-Term Languages Canada } \\
\text { Students }\end{array}$ & $\$ 788.162 .180$ & $\$ 455.708 .000$ & 10.780 & $\$ 48.108 .400$ \\
\hline Additional Tourism Benefits & $\$ 336.389 .440$ & $\$ 187.680 .000$ & 5,550 & $\$ 9.739 .000$ \\
\hline Grand Total & $\$ 8.046 .498 .620$ & $\$ 4.878 .386 .000$ & 86.570 & $\$ 455.039 .100$ \\
\hline
\end{tabular}

Source: "Economic impact of international education in Canada - an update" adapted from Roslyn Kunin \& Associates (2012)

As seen in Table 12, in 2010 the long term 218.200 international students in Canada (who stay at least for six months) earned Canadian economy more than 6,9 billion Canadian Dollars. And 136.906 short term international students who got language education in Canada earned Canadian economy nearly 788 million Canadian Dollars. International students spent a total of nearly 8 billion Canadian Dollars and this helped Canada's GDP 4,9 billion Canadian Dollars. Furthermore international students provided 455 million Canadian Dollars of tax revenue for Canada and 86.570 employment for the economy of Canada.

The revenue gained through education is more than the revenue gained from the export of raw aliminium (6 billion Canadian Dollars), plane and space craft (6,9 billion Canadian Dollars) (Roslyn Kunin, 2012).

\subsubsection{New Zealand}

In recent years New Zealand is among the countries that has the most increase in their international students share. In 2000 there were 8.210 international students in New Zealand and this number increased by 399\% and became 40.995 in 2011 (UNESCO, 2012). New Zealand is preferred mostly by Asian students like Malaysian and Chinese students for its convenient prices and geographical proximity. And since the spoken language is English and it has good life standards, it can be said that New Zealand is a strong candidate for its place in international students mobility (Verbik and Lasanowski, 2007).

The Ministry of Education of New Zealand started to conduct a study to determine the effects of international education to its economy in 2012. And it was found out that the fees that primary, secondary and tertiary levels of international students paid was 361 million dollars. In the same year the total value of international students enrolment fees was 2,6 billion dollars and economic added value of that number is 14\% (Ministry of Education New Zealand, 2014). 
Levent, F. (2016). The economic impacts of international student mobility in the globalization process. Journal of Human Sciences, 13(3), 3853-3870. doi:10.14687/jhs.v13i3.3877

Table 13. The Trend in University International Tuition Revenues

\begin{tabular}{|c|c|c|}
\hline $\begin{array}{l}\text { Calendar } \\
\text { year }\end{array}$ & $\begin{array}{l}\text { University international } \\
\text { tuition revenues (\$NZ) }\end{array}$ & Annual \% change \\
\hline 2003 & $\$ 266.917 .015$ & $29 \%$ \\
\hline 2004 & $\$ 343.996 .835$ & $1 \%$ \\
\hline 2005 & $\$ 348.240 .216$ & $-11 \%$ \\
\hline 2006 & $\$ 311.663 .309$ & $-12 \%$ \\
\hline 2007 & $\$ 273.075 .934$ & $-8 \%$ \\
\hline 2008 & $\$ 251.075 .934$ & $6 \%$ \\
\hline 2009 & $\$ 266.969 .203$ & $6 \%$ \\
\hline 2010 & $\$ 284.008 .792$ & $3 \%$ \\
\hline 2011 & $\$ 292.715 .800$ & \\
\hline
\end{tabular}

Source: "New Zealand universities: Trends in international enrolments" adapted from Ministry of Education New Zealand (2012)

The revenue gained from the fees of international students who enrolled in an university in New Zealand are given in Table 13. As seen in Table 13, the total revenue gained from the fees of international students in New Zealand was 266,9 million dollars in 2003 and 292,7 million dollars in 2011.

\subsection{Policies toward increasing the number of international students}

Competition for attracting more international students among countries and universities plays an active role in shaping the national higher education policy. In this regard, developed and developing countries use different strategies by identifying the policies through civil society organizations, governments and ministry of education (Pusser and Turner, 2004).

America left most of the policies and strategies of the mobility of students to independent organizations and private companies. This has revived the rivalry for international student market in the country (Bhandari, Belyavina and Gutierrez, 2011). US higher education strategy reflects the need for an efficient balance of skilled labor by economic motives. According to Paarlberg (2004), \%30 of doctoral graduates located in R\&D works in the United States is also citizen of another country beside US. Additionally, America supports the Fulbright Program composed of public funds managed by a non-governmental organization, the Institute of International Education (IIE). Fulbright program which is the largest training program created with federal funding meets the cost of the American and international students over 7000 in higher education. This program is active in 150 countries and it is growing rapidly with the support of other universities (Bashir, 2012).

In the United Kingdom, there is a national advisory board for serving international students called UKCISA (UK Council for International Student Affairs). The purpose of this board is to increase the support given to international students, to create awareness in the society about the benefits of the country's international education, to contribute to the professional development of staff working in the relevant departments to determine the factors that negatively affect international student mobility and to eliminate (UKCISA, 2016).

In order to be more effective in international education economy British government has created a program called "Prime Minister's Initiative for International Education (PMI2)". Created by the Prime Ministry, this program covers 5-year strategic plan to ensure the integration of international education economy of the United Kingdom (Leggetter and Sapsed, 2011). The main objective of this plan is to increase the recognition of educational institutions in UK at the 
Levent, F. (2016). The economic impacts of international student mobility in the globalization process. Journal of Human Sciences, 13(3), 3853-3870. doi:10.14687/jhs.v13i3.3877

international level, to provide relations between students abroad and English training institutions, to enhance international students' experience in the UK and to facilitate the employment of international students in the UK (Shangbo, 2015).

France is a country with various national policies and legislation in order to increase student mobility. Recruitment supported by state aid, more effective and flexible visa applications, entitlement to receive some credit and the provision of opportunities for permission to work after school as well as the cooperation of consulates and embassies for submission of scholarship opportunities to improve the situation of international students are considered amongst these policies (Douglass and Edelstein, 2009).

Australian Education International (AEI) is a public institution dependent on Education, Science and Education Ministry of The Australian Government for its operations and carrying out activities of strengthening their cooperation in international education, policy development, service quality and enrichment of students' experiences (WES, 2011). Additionally, Australian Trade Commission (Austrade) promotes the education sector in international markets and helps by providing information to service providers in the country (Development Research Center, 2014). International education activities in Australia are coordinated and policies are produced to increase the number of international students through these two institutions.

In the countries that come into prominence for internationalization, economic support besides technical support are provided by the state institutions that are active in this regard. For example, according to the 2010 data of AEI (2012) the Australian Government has allocated \$200 million for international scholarships. However, Australia has allocated 40 million Australian dollars to graduate students for encouraging international research awards.

VET and ELICOS have become an industry in Australia, and provide very high quality training. VET is widely preferred by international students who wish to embark on careers without studying university. Because the VET sector in Australia is progressing in collaboration with government and industry. Australian government supports this sector very much to increase the workforce (Australian Government Department of the Prime Minister and Cabinet, 2014). Additionally, the qualifications and training standards of ELICOS offering high standard of English language education are supervised by the National ELICOS Accreditation Scheme (NEAS). Australian law does not allow the operation of a language school not recognized by NEAS to keep the high quality of the courses offered to international students (Australian Government Australian Skills Quality Authority, 2012).

In partnership with the Council of Ministers of Education (CMEC) and heads of state in Canada, a plan has been developed and been implemented in all of education districts to improve student mobility and to continue the same mission in education after graduation. In line with this plan studies have been carried out to increase Canada's share of the international student market (CMEC, 2011). National policies of hiring international students in Canada, and to employment in government offices have been in existence for more than 10 years. Private companies in this country employ $20 \%$ of international students who graduate from universities offering International Diploma Program (IDP). In addition, international students with at least 2 years work experience in Canada are offered the opportunity to stay in this country permanently (Douglass and Edelstein, 2009).

When examining policies to international education in the world, Asian countries shows that they want to play an active role in this area. In particular, China is a country preparing to play an important role in the international student market. China has hosted 110.079 international 
students in the year 2012 and aims to increase this number to 500.000 in 2020 . Towards this goal, the Chinese government is working to support the international student recruitment. China Scholarship Council, providing 20.000 scholarships for international students in 2010, has brought the figure doubled comparing to 2007 . However, approximately $5,2 \%$ of international students have Chinese government scholarships. South Korea has made significant improvements in state grants to attract the international students in 130 different countries. In this regard, the South Korean government devoted $\$ 600$ million to the study of "World Class University Project" (Douglass and Edelstein, 2009). With Asian countries, South Africa is growing in popularity especially in the African Continent and hosts 42.351 of international students in the world (UNESCO Institute for Statistics, 2016).

\section{Conclusion}

Today, the international student market has reached a remarkable economic size. In the coming years, this market is expected to expand more and an increase is estimated in the world of international student mobility. Considering the country that the most preferred by international students, these countries appear to be among the twenty countries with the world's largest and strongest economy. These countries see international students as human resources that contribute significantly to economic development and international competitiveness.

International students provide a direct contribution to the economy of the country they reside, with both their tuition fees paid and the expenses made with their family members to meet the accommodation, expenses of travel and daily needs (Vickers and Bekhradnia, 2007). These students offer employment opportunities indirectly for the citizens of those countries by spending in the countries they study (Wilkinson, Merwood and Masgoret, 2010). In particular, contributing to overcoming the shortage of labor in the countries with declining young population and opening new employment areas with the development of education sector are among the indirect economic benefits of internationalization in higher education (Kapur and Crowley, 2008). In addition to these direct and indirect contributions that international students provide, they also help support the financial sustainability of higher education institutions in the country they study.

Majority of international students are higher education students. Studies and research done by these students provide an added value in the form of "technical data" and "technology production" for the economic development of the host country (Guruz, 2011). International students who are going to study in another country from their own countries bring various knowledge and skills especially in science, engineering and technology with them. The majority of these students are working in the country they study and do not return back to their country. Thus, these individuals serve as administrator, architect, engineer and scientist in the country they visit and they become the driving force in the production of industry and technology (Bratsberg, 1995; Varma, 2007). Therefore many developed countries accept talented students from different countries. Those students become qualified human resource/scientist in host country. Host countries are aiming to keep up with economic and scientific advancements by accepting international students (Wadhwa, 2009).

Leading countries in international education have provided training to many people involved in leadership positions in other countries (Cloete, Bailey, Bunting and Maassen, 2011). The students returning to their homes after graduating, continue the positive relationship with the countries they study. This case has a positive effect upon the political, social, cultural and commercial relations between the two countries (Barber and Morgan, 1987; Altbach, 1989; Altbach, 1998; 
Bevis, 2002; Harrison, 2002; Saxenian, 2005, Slaughter and Rhoades, 2004; Harzing, 2004; Naidoo, 2006; Marcottea, Desrochesb and Poupart, 2007; Soo and Elliott, 2010; NAFSA, 2014).

With the expansion of international student market, countries and higher education institutions are competing vehemently to attract more international students. Australia and New Zealand from the Pacific and Asian countries have been added to the developed countries such as the United States and United Kingdom that took the lead. In addition, the rising Far East and Asian economies such as China, South Korea and Singapore have also accelerated its efforts in this area. Following the integration of particularly Asian countries into the global economy, other countries have also revised the international higher education policy and updated their strategies to the changing competitive conditions. Countries such as South Africa, Cuba and the Czech Republic from different continents and development levels are also attending in this process.

Many countries in the world are making significant investments in this area to become a center of attraction for international education. However, surviving in the international education market depends on the fulfillment of certain conditions. For instance, all factors that may be associated with international education such as tuition fees, living expenses, expertise in foreign language, quality in education, visa procedures, accommodation as well as work opportunities must be taken into account. In other words, countries that want to increase the number of international students need to revise their policies in this area and to build effective strategies in the light of new developments.

\section{References}

Altbach, P. G. \& Bassett, R. (2004). The brain trade, Foreign Policy, 44, 30-31.

Altbach, P. G. (1989). The new internationalism: foreign students and scholars, Studies in Higher Education, 14(2), 125-135.

Altbach, P. G. (1998). Comparative higher education: knowledge, the university, and development. Greenwich, CT: Ablex Publishing Corporation.

Altbach, P. G. (2006). Globalization and the university: Realities in an unequal world. In J. J. F. Forest \& P. G. Altbach (Eds.), International handbook of higher education (Vol I, pp. 121-140). Dordrecht, The Netherlands: Springer.

Altbach, P. G., Reisberg, L., \& Rumbley, L. E. (2009). Trends in global higher education: Tracking an academic revolution. Chestnut Hill, MA: Center for International Higher Education, Boston College.

Altbach, P. G., \& Reisberg, L. (2013). The pursuit of international students in a commercialized world. International Higher Education, 73, 2-4.

Australian Government, Department of the Prime Minister and Cabinet. (2014). Roles and responsibilities in education part B: reform of the Federation White Paper issues paper 4. Retrieved from: $\quad$ https://federation.dpmc.gov.au/sites/default/files/issuespaper/issues paper 4 part b vocational and higher ed.pdf

Australian Education International (AIK). (2012). International education snapshot. Retrieved from AIK: $\quad$ https://internationaleducation.gov.au/Internationalnetwork/Australia/InternationalStrategy/IEAC2/Consultation(IEAC)/Documents/Data Snapshot.pdf

Australian Government, Department of Education and Training (2014). End of year summary of international student enrolment data. Retrieved from: https://internationaleducation.gov.au/research/International-StudentData/Documents/Monthly $\% 20$ summaries $\% 20$ of $\% 20$ international $\% 20$ student $\% 20$ enrol ment $\% 20$ data $\% 202014 / 12$ December 2014 MonthlySummary.pdf 
Levent, F. (2016). The economic impacts of international student mobility in the globalization process. Journal of Human Sciences, 13(3), 3853-3870. doi:10.14687/ihs.v13i3.3877

Australian Government Australian Skills Quality Authority (2012). English Language Intensive Courses for Overseas Students (ELICOS). Retrieved from: http://www.asqa.gov.au/cricosregistration/english-language-intensive-courses/english-language-intensive-courses-foroverseas-students-(elicos).html

Barber, E. G. \& Morgan, R. P. (1987). The impact of foreign graduate students on engineering education in the United States, Science, 236(4797), 33-37.

Bashir, M. (2012). Fulbright program for foreign students and the study of public administration. Journal of Public Affairs Education, 18(1), 229-237.

Bergerhoff, J., Borghans, L., Seegers, P.K. \& van Veen, T. (2013). International education and economic growth (IZA Discussion Paper No. 7354). Bonn: Institute for the Study of Labor (IZA). Retrieved from: http://ftp.iza.org/dp7354.pdf

Bessette, R. W. (2003). Measuring the economic impact of university-based research. The Journal of Technology Transfer, 28(3-4), 355-361.

Bhandari, R., Belyavina, R. \& Gutierrez, R. (2011). Student mobility and the Internationalization of higher education: National policies and strategies from six world regions (A Project Atlas Report), New York.

Bleaney, M.F., Binks, M.R., Greenaway, D., Reed, G.V. \& Whynes, D.K. (1992). What does a university add to its local economy, Applied Economics, 24, 305-311.

Bloom, D. E. (2006). "Education in a globalized world”. In M. Sánchez Sorondo, E. Malinvaud, \& P. Léna (Eds.), Globalization and education. Proceedings from a Joint Working Group of the Pontifical Academy of Sciences and the Pontifical Academy of Social Sciences, November 2005, Vatican City.

Borjas, G. (2009). Immigration in high-skill labor markets: The impact of foreign students on the earning of doctorates, in Freeman R. \& Goroff D. (eds.). Science and engineering careers in the United States: an analysis of markets and employment, Chicago: University of Chicago Press.

Böhm, A., Follari, M., Hewett, A., Jones, S., Kemp, N., Meares, D., Pearce, D., \& Van Cauter, K. (2004) Vision 2020: forecasting international student mobility - a UK Perspective, British Council, Universities UK and IDP Education Australia, London.

Bratsberg, B. (1995). The incidence of non-return among foreign students in the United States. Economics of Education Review, 14(4), 373-384.

Brooks, R. \& Waters, J. (2010). Social networks and educational mobility: the experiences of UK students, Globalisation, Societies and Education, 8(1), 143-157.

Cao, X. (1996). Debating brain-drain in the context of globalization. Compare, 26(3), 269-284.

Cloete, N., Bailey, T., Pillay, P., Bunting, I., \& Maassen, P. (2011). Universities and economic development in Africa. CHET: Compress.

Cohen, L., Manion, L., \& Morrisson, K. (2000). Research methods in education (5th Ed.). London: Routlenge Falmer.

Council of Ministers of Education, Canada (CMEC). (2011). Bringing education in Canada to the world, bringing the world to Canada: An international education marketing action plan for provinces and territories.

Retrieved

from: http://www.cmec.ca/Publications/Lists/Publications/Attachments/264/COF Bringing Ed to Canada Eng final.pdf

de Wit, H., \& Hunter, L. (2014). Europe's 25 years of internationalization. International Higher Education, 74, 14-15.

DeVoretz, D. J. (2006). The education, immigration and emigration of Canada's bighly skilled workers in the 21st century, Washington DC: Georgetown's Institute for the Study of International Migration.

Docquier, F., Lohest, O. \& Marfouk, A. (2007). Brain drain in developing countries. World Bank Economic Review, 21(2), 193-218.

Douglass, J. A. \& Edelstein, R. (2009). The global competition for talent. Center for Studies in Higher Education Research \& Occasional Paper Series: CSHE.8.09, 1-22. 
Levent, F. (2016). The economic impacts of international student mobility in the globalization process. Journal of Human Sciences, 13(3), 3853-3870. doi:10.14687/jhs.v13i3.3877

New Zealand Ministry of Education. (2008). The economic impact of export education. Retrieved from: http://www.educationcounts.govt.nz/publications/international/35324/35364

Forbes, L. \& Hamilton, J. (2004). Building an international student market: educational-balanced scorecard solutions for regional australian cities. International Education Journal, 5(4), 502520.

Funk, D. L. (2001). "The impact of international education". (Unpublished doctoral dissertation), University of Wisconsin-Madison.

Guruz, K. (2011). Higher education and international student mobility in the global knowledge economy, SUNY. Retrieved from: http://www.sunypress.edu/pdf/62192.pdf

Harzing, A.-W. (2004). Ideal jobs and international student mobility in the enlarged European Union. European Management Journal, 22(6), 693-703.

Her Majesty's Government (2013). International education: global growth and prosperity. Retrieved from: https://www.gov.uk/government/uploads/system/uploads/attachment data/file/34060 0/bis-13-1081-international-education-global-growth-and-prosperity-revised.pdf

HSBC. (2014). International education. Retrieved from: http://www.hsbc.com/news-andinsight/2014/international-education

Institute of International Education. (2015). "International students by primary source of funding, 2014/15." Open Doors Report on International Educational Exchange. Retrieved from: http://www.iie.org/Research-and-Publications/Open-Doors/Data/InternationalStudents/Primary-Source-of-Funding/2014-15

Ivy, J. (2001). Higher education institution image: A correspondence analysis approach. The International Journal of Educational Management, 15(6/7), 276-282.

Kahanec, M., \& Králiková, R. (2011). Pulls of international student mobility. Bonn: IZA.

Kapur, D. \& Crowley, M. (2008). Beyond the ABCs: higher education and developing countries. Center for Global Development Working Papers, No. 139. Retrieved from: http://www.cgdev.org/files/15310 file HigherEd.pdf

Kelo, M., Teichler, U. \& Wächter, B. (eds.) (2006). Eurodata: Student mobility in European higher education. Bonn: Lemmens.

Lee, J. J. \& Rice, C. (2007). Welcome to America? International student perceptions of discrimination. Higher Education, 53(3), 381-409.

Leggetter, S. \& Sapsed, S. (2011) Developing, enhancing and sustaining research skills in a diverse population of students undertaking a Masters in Public Health: an action research study. Retrieved from: http://www.g-casa.com/conferences/vietnam/paper/Leggetter.pdf

Macready, C. \& Tucker, C. (2011). Who goes where and why? An overview and analysis of global education mobility. New York: Institute of International Education.

McLachlan, D. A. \& Justice, J. (2009). A grounded theory of international student well-being. The Journal of Theory Construction and Testing, 13(1), 27-32.

Maringe, F. (2006). University and course choice: implications for positioning, recruitment and marketing. International Journal of Educational Management, 20(6), 466-79.

Maringe, F. \& Carter, S. (2007). International students' motivations for studying in UK HE: Insights into the choice and decision making of African students. International Journal of Education Management, 21(6), 459-475.

Mazzarol, T., \& Soutar, G.N. (2002). Push-pull factors influencing international student destination choice. International Journal of Educational Management, 16(2), 82-90.

Ministry of Education New Zealand (2014). New Zealand schools-trends in international enrolments. Retrieved

from:

https://www.educationcounts.govt.nz/ data/assets/pdf file/0007/149344/Internation al-enrolments-in-NZ-schools,-July-2014.pdf

Ministry of Education New Zealand (2012). New Zealand universities: Trends in international enrolments. Retrieved 
Levent, F. (2016). The economic impacts of international student mobility in the globalization process. Journal of Human Sciences, 13(3), 3853-3870. doi:10.14687/jhs.v13i3.3877

http://www.educationcounts.govt.nz/ data/assets/pdf file/0010/115030/NZUniversities-Trends-in-International-Enrolments.pdf

Mok, K. H. (2003). Globalisation and higher education restructuring on Hong Kong, Taiwan and mainland China, Higher Education Research and Development, 22(2), 117-129.

Mok, K. H. (2010). The global economic crisis and educational development: responses and coping strategies in Asia. Journal of Education Policy, 25(6), 777-784.

Moor, B. \& Henderkx, P. (2013). International curricula and student mobility. LERU: Advice Paper. No.12, Retrieved from: ftp://ftp.esat.kuleuven.ac.be/sista/ida/reports/13-78.pdf

NAFSA. (2014). The economic benefit of international students-Economic analysis for academic year 20132014. Retrieved from: http://www.nafsa.org/ /File/ / eis2014/USA.pdf

NAFSA. (2015). NAFSA international student economic value tool. Retrieved from: http://www.nafsa.org/Explore International Education/Impact/Data And Statistics/ NAFSA International Student Economic Value Tool/

Naidoo, V. (2006). International education: A tertiary-level industry update. Journal of Research in International Education, 5(3), 323-345.

Naidoo, V. (2007). Research on the flow of international students to UK universities: Determinants and implications. Journal of Research in International Education, 6(3), 287-307.

OECD. (2013). Education at a glance 2013: OECD indicators. OECD Publishing. Retrieved from: http://dx.doi.org/10.1787/eag-2013-en

OECD. (2014). Education at a glance 2014: OECD indicators. OECD Publishing. Retrieved from: http://www.oecd.org/edu/Education-at-a-Glance-2014.pdf

Oplatka, I. \& Hemsley-Brown, J. (2010). The globalisation and marketization of higher education: some insights from the standpoint of institutional theory. In: F. Maringe and N. Foskett, eds., Globalization and internationalization in higher education: theoretical, strategic and management perspectives. London: Continuum.

Paarlberg, R. L. (2004). Knowledge as power. International Security, 29(1), 122-151.

Peterson, P. M. (2014). Diplomacy and education: A changing global landscape. International Higher Education, 75, 2-3.

Phang, S.L. (2013). Factors influencing international students' study destination decision abroad. Retrieved from: https://gupea.ub.gu.se/bitstream/2077/32136/1/gupea 207732136 1.pdf

Pimpa, N. (2003). The influence of family on Thai students' choices of international education. International Journal of Educational Management, 17(5), 211-219.

Pusser, B. \& Turner, J. K. (2004). Changing patterns challenging policymakers. Change: The Magazine of Higher Learning, 36(2), 36-43.

Roslyn Kunin \& Associates, Inc. (2012). Economic impact of international education in Canada - an update. Retrieved from: http://www.international.gc.ca/education/assets/pdfs/economic impact en.pdf

Saxenian, A. (2005). From brain drain to brain circulation: Transnational communities and regional upgrading in India and China. Studies in Comparative International Development, 40(2), 35-61.

Shangbo, L. (2015). Preparing for non-european international students: introducing concrete measures for embodying PMI and PMI2 in the United Kingdom. The Journal of J. F. Oberlin University Law, Political Science and Sociology, 6, 55-76.

Slaughter, S. \& Rhoades, G. (2004). Academic capitalism and the new economy. Baltimore, MD: Johns Hopkins University Press.

Smith, R. A. \& Khawaja, N. G. (2011). A review of the acculturation experiences of international students. International Journal of Intercultural Relations, 35, 699-713.

Soo, K. T., \& Elliott, C. (2010). Does price matter? Overseas students in UK higher education. Economics of Education Review, 29, 553-565. 
Levent, F. (2016). The economic impacts of international student mobility in the globalization process. Journal of Human Sciences, 13(3), 3853-3870. doi:10.14687/ihs.v13i3.3877

Suter, B. \& Jandl, M. (2006). Comparative study on policies towards foreign graduates - study on admission and retention policies towards foreign students in industrialised countries. Vienna: International Centre of Migration Policy Development.

Teichler, U. (1999). Internationlisation as a challenge for higher education in Europe. Tertiary Education and Management, 5(1), 5-23.

UKCISA (UK Council for International Student Affairs). (2016). What is UKCIS A? Retrieved from: http://www.ukcisa.org.uk/What-is-UKCISA

UNESCO Institute for Statistics. (2016). Global flow of tertiary-level students. Retrieved from: http://www.uis.unesco.org/Education/Pages/international-student-flow-viz.aspx

Universities UK. (2011). Driving economic growth: higher education - a core strategic asset to the UK. Retrieved

from: http://www.universitiesuk.ac.uk/highereducation/Documents/2011/DrivingEconomic Growth.pdf

Universities UK. (2014). The funding environment for universities 2014: International students in higher education: the UK and its competition. Retrieved from: http://www.universitiesuk.ac.uk/highereducation/Documents/2014/InternationalStude ntsInHigherEducation.pdf

Universities UK. (2015). The funding environment for universities 2015: the economic role of UK universities. Retrieved

from: http://www.universitiesuk.ac.uk/highereducation/Documents/2015/TheEconomicRole OfUKUniversities.pdf

WES (World Education Services). (2011). International mobility data sources. Retrieved from: http://wenr.wes.org/2011/04/wenr-april-2011-feature/

Wildavsky, B. (2010). The great brain race: How global universities are reshaping the world. Princeton: Princeton University Press.

Wilkinson, A., Merwood, P. \& Masgoret, A. M. (2010). Life after study: International students' settlement experiences in New Zealand. Wellington: Department of Labour.

Wadhwa, V. (2009). Tapping talent in a global economy: A reverse brain drain. Issues in Science and Technology, 25(3), 45-52.

Varghese, N.V. (2008). Globalization of higher education and cross-border student mobility, international institute of educational planning. Retrieved from: http://www.unesco.org/iiep/PDF/pubs/2008/Globalization HE.pdf

Varma, R. (2007). Changing borders and realities: Emigration of Indian scientists and engineers to the United States. Perspectives on Global Development and Technology, 6(4), 1-18.

Verbik, L., \& Lasanowski, V. (2007). International student mobility: Patterns and trends. London: Observatory of Borderless Higher Education.

Vickers, P., \& Bekhradnia, B. (2007). The economic costs and benefits of international students. Oxford: Higher Education Policy Institute. Retrieved from: http://www.hepi.ac.uk/wpcontent/uploads/2014/02/32Economiceffectsofinternationalstudents.pdf

Zheng, J. (2010). Neoliberal globalization, higher education policies and international student flows: an exploratory case study of Chinese graduate student flows to Canada. Journal of Alternative Perspectives in the School Sciences, 2(1), 216-244. 